Article

\title{
McSustainability and McJustice: Certification, Alternative Food and Agriculture, and Social Change
}

\author{
Maki Hatanaka \\ Department of Sociology, College of Humanities and Social Sciences, \\ Sam Houston State University, Campus Box 2446, Huntsville, TX 77341, USA; \\ E-Mail: maki.hatanaka@shsu.edu; Tel.: +1-936-294-4432 \\ External Editor: Douglas H. Constance
}

Received: 15 September 2014; in revised form: 31 October 2014 / Accepted: 4 November 2014 / Published: 14 November 2014

\begin{abstract}
Alternative food and agriculture movements increasingly rely on market-based approaches, particularly voluntary standards and certification, to advance environmental sustainability and social justice. Using a case study of an ecological shrimp project in Indonesia that became certified organic, this paper raises concerns regarding the impacts of certification on alternative food and agriculture movements, and their aims of furthering sustainability and justice. Drawing on George Ritzer's McDonaldization framework, I argue that the ecological shrimp project became McDonaldized with the introduction of voluntary standards and certification. Specifically, efficiency, calculability, predictability, and control became key characteristics of the shrimp project. While the introduction of such characteristics increased market access, it also entailed significant costs, including an erosion of trust and marginalization and alienation of farmers. Given such tradeoffs, in concluding I propose that certification is producing particular forms of environmental sustainability and social justice, what I term McSustainability and McJustice. While enabling the expansion of alternative food and agriculture, McSustainability and McJustice tend to allow little opportunity for farmer empowerment and food sovereignty, as well as exclude aspects of sustainable farming or ethical production that are not easily measured, standardized, and validated.
\end{abstract}

Keywords: standards; certification; alternative food and agriculture; market-based approaches; shrimp aquaculture; social movements 


\section{Introduction}

Alternative food and agriculture movements have proliferated and become a significant component of the global agrifood system [1]. Such movements seek to counter the industrialized, output-oriented, and standardized character of much of food and agriculture. Put differently, the raison d'être of alternative food and agriculture movements is to develop agrifood systems that are diverse and democratic, produce safe and quality food, and embody social justice and environmental sustainability.

Historically, organizations seeking to reform food and agriculture focused on pressuring the state to pass legislation and fund alternative agrifood research and development (e.g., Sustainable Agriculture Research and Education in the US). With ongoing neoliberalization further constraining the regulatory capacity of states [2], however, many alternative food and agriculture movement organizations began to turn to market-based approaches in the 1990s. Among the most prominent market-based approaches is the use of voluntary standards and certification [3-5]. The outcome has been an explosion of standards and certification programs for social, labor, and environmental issues. The most well known include organics [6,7], fairtrade [8,9], sustainable fisheries and aquaculture [10-12], sustainable agriculture [13,14], sustainable biofuels $[15,16]$, and fair and safe working conditions for processing factory and plantation labor (SA8000) [5,17].

Given that alternative food and agriculture movement organizations are increasingly using market-based approaches, performance in the marketplace is a key measurement of movement success. Namely, sales and the number of actors - e.g., producers, processors, and retailers - who are part of alternative production systems have become important indicators of movement success. From such a market perspective, much of the alternative food and agriculture movement is having success, as the number of alternative agrifood products continues to proliferate, sales continue to increase, and the number of actors who are part of alternative agrifood chains continues to grow. For example, sales of organic products continue to rise and organic food and drink sales worldwide reached almost $\$ 64$ billion in 2012 [18]. Retail sales of fair trade products are also growing with sales reaching $£ 1.32 \mathrm{bn}$ in 2011, a $12 \%$ increase on sales of $£ 1.17 \mathrm{bn}$ in 2010 [19]. Fair trade producer organizations are now found in 63 countries and Fair trade products are sold in over 60 countries [20].

While voluntary standards and certification have helped facilitate the expansion of alternative food and agriculture globally, this paper raises questions regarding the impacts that certification has on the aims of alternative food and agriculture. In this paper, I argue that the turn to market-based approaches generally, and the use of certification specifically, is affecting the structure, practices, and culture of alternative food and agriculture. Specifically, building on George Ritzer's McDonaldization framework [21], I contend that certification may be producing the McDonaldizaiton of alternative food and agriculture initiatives. Ritzer maintains that much of society is coming to resemble fast food restaurants in that it is becoming increasingly organized around principals of efficiency, calculability, predictability, and control. Using a case study of an ecological shrimp project that became organically certified, my argument is that the principles of efficiency, calculability, predictability, and control are becoming organizing principles of certified alternative food and agriculture initiatives.

The ecological shrimp project began in 1992 and connected Japanese consumer cooperative (co-op) members with Indonesian shrimp farmers interested in sustainable aquaculture. Initially, democratic governance and a high degree of trust between shrimp farmers and co-op members characterized the 
project. In 2002, part of the project received organic certification, which led to significant changes in the organization and governance of the project. Specifically, with the introduction of formal standards, documentation, and audits as part of certification, the project became increasingly McDonaldized. The result was hierarchical decision-making, marginalization and alienation of farmers, and a focus on maximizing production. Thus, while certification increase market share for alternative food and agriculture, my findings indicate that such growth may entail tradeoffs. I contend that certification may be resulting in a particular form of sustainability and justice, that is, what I term McSustainability or McJustice.

Data on the ecological shrimp project was gathered using extensive field research in 2004 and 2008. A total of 118 interviews were conducted with a variety of actors involved in shrimp farming in the region, including certified and non-certified shrimp farmers, certified and non-certified warehouse owners, project managers and organizers, hatchery owners, social movement organizations, national and regional government officials, and aquaculture specialists [22]. In 2004, data was collected on the origins of the organic shrimp project, views on certification, the potential implications of the project, and the relationship among different actors associated with the project. In follow-up research in 2008, key informants were re-interviewed to assess the ways in which the implementation of the project had progressed and changes in how actors viewed the project. Both sets of interview data were supplemented by participant observation whenever possible, which focused on the interactions among members of the project. Lastly, content analysis of archival data on shrimp aquaculture, alternative food and agriculture, and certification from websites, newsletters, and reports by transnational organizations, such as the Food and Agriculture Organization, national and international non-governmental organizations, and certification bodies was undertaken.

The remaining sections of the article are organized accordingly. First, Ritzer's McDonaldization framework is reviewed and applied to food and agriculture. In particular, the ways that the industrial food and agriculture system is McDonaldized, and the ensuing development of alternative food and agriculture movements are emphasized. Second, I provide an overview of shrimp aquaculture and social and environmental issues associated with it. Third, a history and overview of the ecological shrimp project is presented. Fourth, I examine the ways that the project became McDonaldized with organic certification, and the implications this has had for the project. In concluding, I introduce the notions of McSustainability and McJustice as an outcome of the McDonaldization of alternative food and agriculture.

\section{McDonaldization, Industrialized Food and Agriculture, and Alternatives}

Building on Max Weber's theory of rationalization [23], George Ritzer [21] observes that high levels of formal rationality and bureaucratization characterize more and more sectors of American society, as well as an increasing number of other societies. He presents the fast-food restaurant as emblematic of this new form of social organization and argues that society is undergoing what he terms "McDonaldization." Specifically, Ritzer identifies four primary components of McDonaldization: efficiency, calculability, predictability, and control. First, efficiency means maximizing output and minimizing inputs. In the context of the fast food industry, this entails the use of organizational rules and regulations to help ensure highly efficient work by employees. For example, the cashiers in fast 
food restaurants tend to use "scripts" to communicate with customers. Such scripting of conversations is designed to minimize the time it takes to serve a customer and thus, maximize the number of customers that can be served.

Second, calculability describes the quantitative character of fast-food restaurants. For example, a key focus of fast food restaurants is the size and cost of meals as well as the time it takes for customers to get their food. In McDonaldized settings, quantity comes to represent quality. The logic behind this is that "a lot of something, or the quick delivery of it, means it must be good" [21] (p. 14). Third, predictability entails ensuring that products and services are the same both across space and time. Many customers take great comfort knowing that fast-food restaurants offer no surprises and they can get the same food regardless of location. For example, McDonaldization enables a person to get the exact same Egg McMuffin in a McDonald's in New York City or in a rural Texas town. In addition to supplying predictability to customers, McDonaldization also makes work experiences predictable in that work is largely standardized both within restaurants and across fast food industry.

Lastly, McDonaldized systems are characterized by significant control over the people who are part of them. In fast food restaurants, skilled work is largely limited to the design and improvement of McDonaldized settings. Thus, most workers have very little autonomy as nearly all processes are prescribed, and the hierarchical structure of McDonaldized settings ensures worker discipline. In other words, workers are little more than cogs in a machine. Similarly, customers are also quite disciplined, as they have to follow a multitude of rules, such as waiting in line, carrying their food, and clearing their own tables. For example, a prominent science and technology scholar, Susan Leigh Star [24], who was allergic to onions, documented how difficult customizing orders are at McDonald's and thus, how little voice customers have regarding what they eat.

From Ritzer's perspective, McDonaldization has both positive and negative effects on society. On the one hand, McDonaldized systems enable society to do many things that were not possible in the near past. They have increased efficiency, product uniformity, and have helped make global standardization possible. Additionally, they tend to be highly profitable for corporations. On the other hand, Ritzer argues such systems can generate what he terms the irrationality of rationality, by which he means that they become so rational they begin producing social issues and problems. For example, fast food restaurants also tend to serve unhealthy food, rely on environmentally degrading forms of agriculture, and be alienating places to work. Thus, McDonaldization is 'double-edged' in that it has both benefits and drawbacks for society [21].

Applying this framework to food and agriculture, the industrial agrifood system can be understood as an example of McDonaldization in food and agriculture. Beginning with the post WWII period, food and agriculture have become increasingly industrialized and organized according to the principles of efficiency, calculability, predictability, and control. For example, in the US, much of agriculture has become characterized by productivity, mechanization, dependence on massive chemical inputs, and the use of standardized crops [25-31]. Thus, similar to fast food restaurants, the industrial agrifood system has largely been structured around the principle of abundant and cheap food [32]. This has led to a reorganization of agriculture in which large farms produce much of the food grown in America. Less than $2 \%$ of Americans are farmers today [33], and in 2007, 125,000 farms produced $75 \%$ of the entire value of US agricultural production, with the average farm size being 418 acres [34]. Additionally, the 
McDonaldization of agriculture has shifted power from farmers to the transnational corporations, such as input companies, processors, and retailers.

While the industrial food and agriculture system is highly productive, it is also characterized by significant irrationalities in the form of a myriad of social and environmental problems. First, given the corporate control of the industrial food system, there are issues associated with transparency, democracy, and accountability. For example, food safety crises continue to be fairly commonplace [35], food insecurity continues to be a global problem [36-38], and food sovereignty for many people is extremely constrained [39-41]. Additionally, the healthiness of food is increasingly questioned given the proliferation of diet-based illnesses and obesity [26,42]. Second, agriculture is beset by a series of environmental problems that threatens its sustainability, including high resource use, water and air pollution, soil depletion, production of greenhouses gases, and loss of biodiversity [26,43,44]. Lastly, labor issues continue to be a problem in much of agriculture at all levels from the farm to the retailer, as such jobs are often low paid, and tend to be characterized by hazardous working conditions [45-47].

Alternative food and agriculture movements can be understood as a response to the McDonaldization of food and agriculture and the plethora of social and environmental problems it has generated. While alternative food and agriculture movements are characterized by significant diversity and embody a variety of causes (e.g., farm worker rights, environmental sustainability, and animal welfare, and nutrition and health), $[48,49]$, they often share the goal of embedding food and agriculture in networks where social, economic, and ecological relations are fair, just, and democratic [50,51].

Historically, alternative food and agriculture movements largely focused much of their efforts on the state. Most notably, this included securing government support for alternative agriculture (e.g., research, funding, and policies), and increased social and environmental regulation of food and agriculture $[13,52]$. However, while such an approach did result in important gains in many places, movement organizations are constrained in the kinds of changed they have been able to achieve, especially with the neoliberalization of many states over the past three decades [2]. Consequently, much of the alternative food and agriculture movements has shifted their efforts to market-based approaches [17,53-55], especially the use of voluntary standards and certification [3,56,57].

Typically, in market-based governance approaches, non-governmental actors develop a set of voluntary social or environmental standards that define alternative forms of production (e.g., environmentally sustainable and/or fair and safe labor conditions). Independent third-party certifiers ensure the implementation of the given standards through the use of audits. Lastly, alternative products are often labeled (e.g., fairtrade and Rainforest Alliance) to differentiate them from conventional products. Thus, through the use of standards and certification alternative food and agriculture movement organizations are working to develop and govern alternative forms of production. If successful and certified alternative products gain significant market share, such movement organizations will be able to shift food and agriculture towards more sustainable and just practices $[4,58]$. In short, in this approach, alternative food and agriculture movements are relying on the "the invisible mouth" [59] - actual and potential consumer demand-as a tool to change food and agriculture. The idea is that by pressuring food and agriculture companies, movement organizations will be able to "harness the profit motive to innovative and efficient social and environmental solutions" [60] (p. 313). Given the success of some alternative food and agriculture initiatives using this approach, such as 
organics and fair trade, the use of voluntary standards and certification by alternative food and agriculture movements is growing $[5,8,10,14,58]$.

While alternative food and agriculture movements are increasingly using certification, and certification has received considerable research attention, there is a dearth of research on the ways that certification may be affecting the structure, practices, and culture of alternative food and agriculture. Thus, a key research question becomes the implications of certification for the internal dynamics of movements, as well as the kinds of social and environmental changes that can be achieved. To begin to address this research gap, using Ritzer's McDonaldization framework the remaining portions of this article examine the transformations that occurred in an ecological shrimp project after it received organic certification.

\section{Aquaculture: Industrialization and Alternative Movements}

Seafood consumption is rising globally. Consequently, the proportion of marine fish stocks estimated to be overexploited (i.e., fished beyond sustainable yield) or depleted is increasing. In 2010, the Food and Agriculture Organization (FAO) estimated that 53\% of the world's marine fish stocks were fully exploited (at their maximum sustainable limits), 28\% overexploited, and 3\% depleted [61]. Given the highly stressed state of fisheries, aquaculture is rapidly becoming a more significant source of seafood. Today, it is the fastest growing segment of animal-food production, with an average annual growth rate of 6.6 percent [61]. Approximately half of the global seafood supply now comes from aquaculture, and estimates indicate that aquaculture's portion will continue to grow in the future [62].

While geographical expansion has been a key component to increasing aquaculture production, intensification has also been a significant factor. Similar to the green revolution, which industrialized much of agriculture in the global South, the blue revolution industrialized much of aquaculture, particularly high-value species such as shrimp [63]. For shrimp farming, the result has been a shift from traditional, extensive forms of shrimp farming towards greater use of industrialized aquaculture practices [64]. Specifically, the industrialized shrimp aquaculture has entailed increases in stocking densities, greater pond density, and the introduction of synthetic inputs, such as feed, antibiotics, medications, and pesticides. Similar to livestock operations, there has also been a shift to large firms controlling much of shrimp aquaculture through vertical coordination $[65,66]$. The result has been that feed, hatcheries, farming, and processing are becoming increasingly consolidated and concentrated [62,63]. In short, with industrialization, aquaculture has become McDonaldized in that efficiency, calculability, predictability, and control characterize much of shrimp aquaculture today.

While the blue revolution produced tremendous increases in productivity, a host of social and environmental issues have also accompanied it. First, the geographical expansion and increased pond density has led to degradation of coastal environments, especially mangroves [67,68]. Second, with the shift towards a few high value species, there has been a loss of genetic diversity, which affects susceptibility to disease and environmental stresses [62]. Third, chemical use has created concern over water pollution and the effects on neighboring ecosystems [69]. Fourth, there has been a growth of land and resource conflicts, with farmers and communities losing access to coastal lands in some instances [70]. Lastly, research indicates that inequality tends to increase with the industrialization of aquaculture $[71,72]$. 
In response to such social and environmental concerns, as well as food safety issues, multiple efforts to govern and/or reform industrialized shrimp aquaculture have emerged. Increasingly prominent are market-based approaches that use voluntary standards and certification [12,73-77]. Today, multiple non-governmental organizations set voluntary standards for sustainable aquaculture and certify their compliance, including international certification bodies, such as the Soil Association, Naturland, and the International Federation of Organic Agriculture Movements. The international trade association, the Global Aquaculture Alliance, as well as leading global retailers, GlobalGAP, have also developed aquaculture standards that address sustainability and justice issues and use certification respectively. Furthermore, the Consortium on Shrimp Farming and the Environment, which includes the Food and Agriculture Organization (FAO), the Network of Aquaculture Centres in Asia-Pacific, the United Nations Environmental Programme, the World Bank, and the World Wildlife Fund, has launched the Aquaculture Stewardship Council to oversee the implementation of sustainability standards for a range of aquaculture products, including shrimp. Thus, the use of voluntary standards and certification is becoming a key approach to counteracting the negative effects of industrial aquaculture today.

\section{The Ecological Shrimp Project}

The ecological shrimp project is located on the eastern coast of the island of Java in Bojokulu. Bojokulu is an area that has long been known as a milkfish and shrimp farming site. Farmers in Bojokulu have used traditional aquaculture practices for over 300 years. Traditional shrimp farming practices entail a poly-cultural system, rely on the surrounding ecosystem to supply shrimp feed, and replace water in shrimp ponds (tambak) using tidal flows [78]. Thus, they tend to use minimal artificial inputs, such as shrimp feed, supplements, antibiotics, synthetic chemical pesticides and fertilizers. Beginning in the 1980s, the Department of Marine Affairs and Fisheries introduced blue revolution technologies and practices to shrimp farmers in the region. Many of the local shrimp pond owners who could afford to implement such technologies and practices did so and moved away from traditional practices. While shrimp output increased, the adoption of blue revolution practices and technologies has also led to a myriad of social and environmental problems.

It is against this backdrop that a Japanese NGO, Sustainable Network (SN), initiated an ecological shrimp project in Bojokulu in 1992. SN was originally funded by several progressive Japanese co-op organizations, whose mission is to increase the sustainability and justice of food and agriculture. Embodying the goals of the co-op, the ecological shrimp project sought to secure safe and quality shrimp for co-op members, promote environmental sustainability in Bojokulu, and improve the economic welfare of shrimp farmers. To accomplish these goals it worked to link shrimp farmers who use traditional practices with co-op members in Japan. Building on their commitment to food sovereignty, co-op members believed that partnering with shrimp farmers would lead to better understanding of each other's needs and interests. This would enable the development of a shrimp supply chain that was beneficial for all stakeholders. To accomplish this, a key component of the ecological shrimp project was building personal relations and trust between co-op members and shrimp farmers.

From the very beginning of the ecological shrimp project, $\mathrm{SN}$ worked to facilitate relations between Japanese co-op members and Indonesian shrimp farmers. For example, to begin to overcome cultural 
and language barriers, SN hired an Indonesian aquaculture specialist who was originally from the region, and who had received his Ph.D. in aquaculture at a Japanese university. SN officials and a group of co-op members also traveled to Bojokulu multiple times, where they visited shrimp ponds and warehouses, and discussed with farmers what should be the appropriate criteria for "sustainable shrimp farming". These efforts brought to light several differences between Indonesian farmers and Japanese co-op members regarding sustainability that would need to be bridged for the project to be successful.

The most notable difference between farmers and co-op members was the use of chemical inputs. At the time, farmers got their fry from hatcheries where application of antibiotics was common. Some farmers also used chemical pesticides in their ponds to kill predatory animals, such as snakes. In contrast, from the perspective of SN and co-op members, sustainable farming did not include the use of chemicals. Through a series of discussions a compromise was reached in which the Japanese co-op members accepted the use of antibiotics at the hatcheries, given the lack of technological resource available to produce fry without antibiotics, and the farmers agreed to stop using synthetic chemicals in their ponds.

Once standards were established and the project was up and running, implementing the standards was the responsibility of farmers. Farmer compliance with the standards was not formally monitored. Building on the process used to develop the standards, SN worked to build further relationships between farmers and co-op members and establish trust. This included continued visits to the pond community in Bojokulu by co-op members and also visits by some farmers to Japan. When co-op members visited the pond community in Bojokulu, they met with farmers, took part in harvesting activities, and had forums with farmers and project managers discussing the project and issues that had arisen. In interviews, farmers expressed that they tended to like the co-op members' visits. For example, one farmer commented,

At least once a year, they came here. They tried to listen to our story. They had tolerance. They at least tried to understand us, and our conditions. There, we can see their respect for us. Therefore, we also tried to understand them.

Another farmer similarly remarked,

We were very happy if consumers actually come to our pond and at least try to know our difficulty and environment of production. It encourages us to produce better shrimp. It's human-to-human relationship, right? We all like that.

SN also arranged for farmers from the project to visit co-op members in Japan on multiple occasions. On such visits, farmers would have discussions with co-op members about the project, visit co-ops, and partake in social functions, such as cooking and eating a meal that included shrimp from the project. Thus, a key part of SN's management included significant efforts to foster communication and build relationships between farmers and co-op members. Consequently, according to interviewees, the ecological shrimp project was initially characterized by high levels of trust and respect between farmers and co-op members.

In 2000, a European buyer approached SN with interest in purchasing shrimp from the project. However, the European buyer requested the project have organic certification from an established certifying body. Compared to the self-assessment the project was using, the potential buyer viewed 
certification as a more reliable form of conformity assessment. SN saw the opportunity for a new market as a way to expand the project and allow more farmers to participate in it. Thus, soon after the European buyer approached them, SN convened an open forum in Bojokulu to gauge local interest in organic certification. They invited project stakeholders, including shrimp warehouse owners, pond owners, NGOs, and government officials. More than 100 people attended the meeting, and an overwhelming majority voiced support for organic certification. Hence, with the support of the Bojokulu shrimp farming community, $\mathrm{SN}$ and a group of shrimp farmers began the process of acquiring organic certification. In July 2002, Green Soil, a leading European certifying body, certified part of the ecological shrimp project as organic and an organic division within the project was established. Subsequently, organic shrimp was sold to the European buyer and ecological shrimp continued to be sold to the Japanese co-ops.

Two years after receiving organic certification the European buyer terminated its contract with the project [79]. However, project managers maintained certification for an additional four years in hope of finding new buyers. In the meantime, shrimp produced in the organic division of the project were sold to Japanese co-ops. Overtime, the project managers found the requirements of certification useful for managing the entire ecological shrimp project, and thus, gradually began to implement parts of them in the ecological shrimp project. This shift in governance led to changes in Japanese co-op members' relationship with the shrimp project. Specifically, while co-op members initially viewed trust-based relations with the farmers as sufficient for ensuring sustainable shrimp, they found certification useful in that it limited their need to be actively involved in the project. Thus, while a formal distinction remained between the organic division and the larger ecological shrimp project, the principles, measures, and the audits of the organic division were increasingly implemented throughout much of the ecological shrimp project.

To entice local farmers to join the project, a high base price was paid to farmers and warehouses in both the ecological and organic divisions. Additionally, a one US dollar premium was paid for each kilogram of organic shrimp, which was divided between the warehouse and shrimp farmers. At the time of my first site visit in November 2004, of the approximately 15,000 hectare of shrimp ponds in Bojokulu, 5000 hectare of ponds were participating in the ecological shrimp project and approximately half of them (2500 hectare) were registered with the organic division of the project. In May 2008, the managers of the ecological project decided not to renew organic certification and terminated the organic division of the ecological shrimp project. The reasons for this decision are discussed below.

\section{Organic Certification: McDonaldization of Sustainable Shrimp Farming}

Prior to certification, democratic and participatory relations in which both farmers and co-op members were able to have a voice characterized the ecological shrimp project. Thus, as noted above, the ecological shrimp project had established strong relations of trust between farmers and co-op members. However, with the introduction of organic certification, the governance of the project and the relationship between farmers and co-op members underwent significant changes. Specifically, the shared governance, mutual understanding, and personalized relationships that had characterized the ecological shrimp project were largely displaced, and the project became rationalized and bureaucratic. In short, the project became increasingly McDonaldized. The three subsections below examine the 
McDonaldization of the project with introduction of formal standards, documentation requirements, and audits.

\subsection{Standards of Sustainable Farming}

McDonaldization is evident in both the standard-development process and the resultant organic standards. Prior to receiving organic certification, the standards used in the ecological shrimp project were the outcome of ongoing dialogue between shrimp farmers and co-op members. Consequently, both farmers and co-op members were able to express their views and have voice in the development of the standards. As a result, the standards were informal, allowed farmers flexibility in the practices they used, were adaptable to changing conditions, and incorporated farmer's experiential and historical knowledge.

With organic certification, both the development of the standards and their content became more formalized. In order to develop "universally applicable" standards, Green Soil bases their standards on scientific knowledge and best practices. As scientific knowledge is commonly perceived to be impartial and culturally neutral, science-based standards are thought to exclude bias and personal preferences [80,81]. In developing the organic standards, Green Soil proposed the following process. First, Green Soil would share its core principles and general organic standards with the projects managers of the ecological shrimp project. Second, project managers would put together a local standard-development committee to adapt the general organic standards to shrimp aquaculture in Bojokulu. Lastly, Green Soil would review, amend, and approve the standards. From the perspective of Green Soil, developing standards in this way would result in organic standards that are based on scientific evidence, but are also tailored to local conditions.

Following Green Soil's proposal, the managers of the ecological project established a local standard-development committee to tailor Green Soil's standards to the conditions of Bojokulu. The committee consisted of four famers from the ecological shrimp project who had long been using sustainable farming practices and an aquaculture specialist who assisted in developing the ecological shrimp project. However, while formally the committee was given the opportunity to amend the standards, they quickly realized that their ability to do so was constrained. Specifically, committee members found their proposed changes were often not accepted because they were not based on scientific knowledge, but experiential knowledge they had gained through farming. In other words, because the knowledge of the committee was not calculable in that it was not easily quantifiable and not supported by tangible evidence, it lacked legitimacy in the eyes of Green Soil. Hence, committee members noted that they felt marginalized in the standard-development process and that their perspective was not respected.

The organic standards that resulted from the process were much more calculable than the standards of the ecological project. Specifically, they established quantifiable metrics that farmers are required to comply with, including: specified stock density (maximum: three seedlings $/ \mathrm{m}^{2}$ ), the use of polyculture with milkfish, specified location of ponds (with a minimum of seven meters between the rim of the ponds and river), no chemical inputs, the planting of mangrove trees around the ponds and their dikes (with a maximum of seven meters between trees), and various documentation requirements. As the standards were based on Green Soil's core organic principles, they also resulted in the standardization 
of both farming practices and the shrimp produced in the project. In this way, the ecological shrimp project became predictable in that it adhered to similar standards to Green Soil's other organic certified projects. Lastly, as farmers had little input into the development of the standards, the standards functioned as a form of control in that they specified to farmers how to sustainably farm shrimp.

\subsection{Documenting Sustainable Farming}

Prior to organic certification, co-op consumers largely trusted farmers to follow the standards. Hence, farmers were almost entirely accountable for conformity-assessment. With organic certification, a formalized and bureaucratic governance structure was developed. Specifically, an array of documentation templates for farmers and inspectors was developed to evaluate farmer and warehouse practices. This resulted in efficiency, calculability, predictability, and control becoming prevalent characteristics of the project.

As part of organic certification, Green Soil required the development of an internal control system (ICS). An ICS is a document and audit based conformity-assessment system for ensuring compliance with the standards. To develop and manage the ICS a local organization, Perlindungan Alam (PA), was established. One of the initial tasks of PA was to develop documentation templates to assess farmer compliance with the standards. Similar to the standard-development process, Green Soil provided model templates, PA then tailored them to the project, and Green Soil amended and approved them.

The documentation requirements entailed, first, that farmers who were interested in joining the organic project register their ponds. Following registration, officials from PA would visit the farmers to explain the project and inspect the ponds. Next, if a farmer was approved to join the project, they had to a sign a membership agreement form, which established a contractual agreement between PA and the farmer. The contract specified that the farmer consented that he understood the standards and agreed to adhere to them. Upon joining the project, PA created a membership file for each farmer, which contained information on the farmer and his ponds.

Once farmers became part of the organic project, they had to complete production documentation forms that detailed their farming activities. Necessary information included when, how much and from which hatchery they got their shrimp fry, when and how much of the shrimp and milkfish fry they released into the pond(s) [82], and date and usage of the organic pesticide, and information on any other inputs that they used. Farmers also had to complete harvest documentation forms that detailed the date and time harvesting began and ended, and how much and which kinds of shrimp and milkfish were harvested from which pond.

Similar to the introduction of formal standards, the development and implementation of documentation practices also led to the McDonaldization of shrimp farming. First, as the documents became the official record of farmer compliance with the standards, the information required by the documents became the most significant measurements for assessing the sustainability of farmer practices. The result was increased calculability in that the recorded information in the documentation forms became the priority, as opposed to the actual sustainability of farming practices. Second, the use of standardized documentation templates increased predictability throughout the project. Specifically, it contributed to the standardization of not only the shrimp, but also farmer practices and the ways that farmers (and inspectors) evaluate their practices. Third, the use of standardized documentation 
templates also increased the efficiency of governing the project, as the same set of documents could be used to assess all farmers. Lastly, the documentation templates functioned as a form of control in that they established rules and requirements that farmers had to abide by. In other words, combined with the formalized standards, the documentation requirements further prescribed to farmers how to farm and measure their practices.

\subsection{Auditing Sustainable Farming}

In addition to document requirements, farmers were also subject to audits as part of the conformity assessment process with organic certification. Specifically, farmers were incorporated into a multilayered audit system that consisted of ICSs, certification bodies, and accreditor organizations (see Figure 1). The introduction of such conformity assessment practices and their implementation across the ecological shrimp project displaced the personalized relationships and trust that were part of the ecological shrimp project. The result was the further McDonaldization of the project as audits increased efficiency, calculability, predictability, and control in the project.

With the development of a multilayered audit system, shrimp farmers had to undergo a series of audits by PA as part of the ICS. For example, each pond had to have at least one unannounced inspection per production cycle (i.e., 90 days). Additionally, inspectors were also required to be at ponds during harvest time to oversee the shrimp harvest. During audits, inspectors would typically examine farmers' documentation, question farmers as to their practices, complete inspection documents, and search the huts and ponds for chemical input packages or containers. Following inspections, farmers were evaluated and assigned a pass or fail grade. If they passed, they could sell their shrimp as organic and receive the price premium. Audit results were recorded and if a farmer failed three consecutive audits they faced termination from the organic project. This indicates that with the introduction of audits formal sanctions also became part of the project.

Figure 1. Multilayered Audit System in the Organic Shrimp Project.

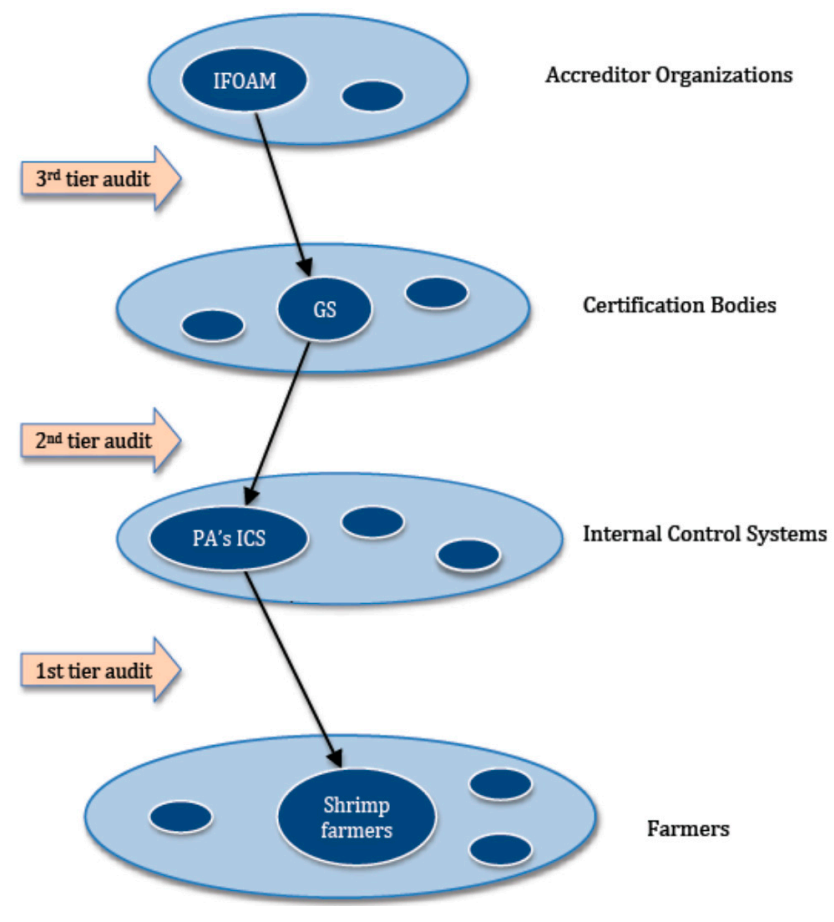


In addition to farmers, Green Soil also assessed PA and the ICS annually. Green Soil would send a team of external auditors to Bojokulu to conduct the audit. Auditors would audit a random sample of the documentation filled in by both farmers (approximately $15 \%$ to $20 \%$ of member farmers) and PA inspectors. They would also visit a random sample of ponds and take soil and water samples, and question farmers regarding their farming practices. Similar to the audits of farmers, Green Soil also issued a pass or fail grade to PA and the entire organic shrimp project. In order to stay certified, the project had to pass its annual audit. Lastly, Green Soil was also audited annually. As part of its accreditation process, the International Federation of Organic Agriculture Movements (IFOAM) audited Green Soil to ensure that its certification process was objective, transparent, and effective.

The implementation of these multilayered audits resulted in the significant McDonaldization of the project. First, at all levels, that which is being audited must be measurable and thus, based on tangible evidence. Additionally, it must be objective in the sense that it is, at least in principle, independently verifiable. In short, audits imply calculability and the application of audits across the organic shrimp project resulted in calculability becoming a central characteristic. Second, a key function of the multilayered audit system was essentially to standardize all aspects of the project, including the standards, farmer practices, the shrimp, the documentation templates, and the auditing practices themselves. Hence, the introduction of audits contributed to making a differentiated product — organic shrimp - predictable. This meant that the shrimp were supposedly produced using practices similar to other organic shrimp from different sites. Third, the multilayered audit system increased the efficiency of governing the organic shrimp product. Specifically, the use of standardized audit practices, in conjunction with the documentation templates, lessened the skill, knowledge, and resources needed to monitor farmers and their practices.

Lastly, the multilayered audit system functioned as a system of control in that it disciplined farmers, project managers, and Green Soil. As it was a hierarchical system, whether or not farmers were farming sustainably, whether or not the project sufficiently complied with standards, and the degree to which Green Soil was competent were largely decided in a top-down manner. For example, if farmers did not pass audits they were removed from the project, if too many farmers did not meet the standards, the project could potentially be de-certified, and if Green Soil was not an effective certifying body it could be de-accredited.

\section{Implications of McDonaldization}

The McDonaldization of the ecological shrimp project with organic certification had several positive impacts. First, certification legitimated the project in the eyes of European buyers. This not only enabled farmers to gain access to the organic market in Europe, which offered better prices than conventional markets, but also established their reputation as a high quality shrimp production site. Second, with certification, the efficiency of the project increased. For example, all the rules were prescribed and thus, farmers simply needed to follow the required standards to farm sustainably, and PA officials just had to abide by the inspection standards in checking farmer practices. Third, the increased predictability of the project was also beneficial. For example, post-certification there was less variation in the quality of the shrimp produced, which enhanced its market value. Lastly, the development of formal standards and a conformity-assessment system meant that the European buyers 
and Japanese co-op members no longer had to be as actively involved in the initiative. Thus, they were able to pursue other interests and projects.

However, certification and the ensuing McDonaldization also negatively impacted the project. First, with certification and the formalization of standards and conformity-assessment, less effort went into fostering and maintaining relations of trust. Consequently, trust between farmers and co-op members declined, as well as between project managers and farmers. For example, speaking of the changes in the project, one project manager commented, "contractual agreements are quite stiff and lack flexibility. It's based on rationality, documentation, contracts, and signature. There is no human-to-human relationship entailed." Many farmers expressed unhappiness and frustration with such changes. The following farmer's comment is illustrative of this position:

We really care the ways that we are treated. We want to be treated with respect. The sense of respect is a key component to the Javanese culture. People need to be cared. That's the Javanese people's system... [The project] has become very business oriented now. [The project managers] don't respect us any more.

In other words, personal relationships and relations of trust were largely replaced with notions of efficiency, calculability, predictability, and control, which frustrated and alienated many farmers.

Second, the McDonaldization of the project also affected how communication took place within the project. Specifically, project managers' mediation of communication between farmers and consumers also frustrated some farmers. In interviews, some farmers commented that they now had to play a "message game" in that whenever farmers had a question for co-op members they had to ask the inspectors, who then would deliver the question up the hierarchy to PA officials, then SN officials, and lastly to the co-op members. Speaking of this process, one farmer lamented, "by the time the information gets to us, the content often changes and is unclear." The result of such a bureaucratized communication structure was a further erosion of trust between farmers and co-op members.

Third, the McDonaldization of the project affected the roles of farmers and co-op members to the project, as well as their commitment to the project. Most notable is that many farmers in interviews indicated that they had little say in the project. And, as their performance was evaluated according to the extent to which they conformed to the standards, they felt that they were being treated as objects of control. Speaking of the changes among farmers, an SN official remarked:

With certification, member farmers have become puppets. They just follow the rules that were set up by the certifier. Now, they neither think, nor try to improve their farming practices. They just passively follow all the rules and procedures that were prescribed. They stopped thinking, stopped participating in the project. Thus, their morale became low.

Consequently, commitment by farmers to the project lessened. Similarly, engagement by co-op members decreased as the project became increasingly bureaucratized. For example, speaking of changes in the co-op consumers, a PA official commented in the following manner:

[Japanese] co-op members have definitely changed over time with the certification. Their awareness has become low, no more visits, little understanding of what is going on at the production site... There is no dialogue between consumers and farmers now. What we have now is a very impersonal network. 
Thus, with the introduction of formal standards and a conformity-assessment system, co-op consumers disengaged from the farmers.

Fourth, the McDonaldization of the project eroded the original democratic character of the project. This is evident in the standard-development process, which members of the standard-development committee viewed as hierarchical and undemocratic. For example, one committee member commented of the process:

[Certifiers] develop universal standards based on their own perspectives and ideas. Then, they impose such standards on suppliers throughout the world. They just determine that their standards are the standards... They won't listen to different perspectives or opinions from us. They are not flexible.

Similarly, another committee member noted, "We are not allowed to decide what sustainable shrimp farming is by ourselves. It is our ponds. It is our sustainability." With the implementation of the documentation templates and audits, many farmers expressed that the project had become increasing less participatory. In interviews farmers often noted that they were powerless. The result was that many farmers felt that outsiders were managing the project according to their needs and wants. Given their powerless position, for some farmer simply meeting the standards or not getting caught not-complying with them became their primary objective, as opposed to improving the sustainability of their farming practices.

Lastly, the objectives of the project became increasingly output-oriented following certification. In other words, according to many interviewees, quantification in the form of producing more sustainable shrimp and enlarging the project became key objectives. For example, an official with PA commented, "the project has become increasingly dominated by the idea, 'if you don't sell, you cannot change anything." However, the push to expand the project also resulted in a weakening commitment to the project's original aims. On the one hand, the increasingly output oriented philosophy led to the reconceptualization of farmers as subjects to be controlled who had to be disciplined rather than partners in a joint project to achieve mutual goals, and as a result, the project began to encounter more disagreements, conflicts, and antagonisms. On the other hand, whereas pre-certification the farmers who partook the project were largely committed to the idea of sustainable farming, many of the farmers who joined the project post-certification were primarily interested in the economic incentives and not fully committed to the environmental components of the project. Hence, the number of farmers who were not fully complying with standards and falsifying documents increased.

In sum, while the McDonaldization of the shrimp project had benefits in terms of market access and efficiency, it also had the effect of making it quite similar to industrialized shrimp farming. This is a point that some in the project came to realize. For example, an official with PA commented:

I don't think there is much difference between the intensive shrimp system and organic shrimp system. The only difference between them is that organic shrimp system deals with niche products and that is all. Both focus on producing something that can be sold in the market. To sell the product, you have to make buyers happy, and accommodate with their demands and needs. You begin to prioritize buyers' demands over those of producers to sell. As long as you use market as a tool, this mindset is going to dominate the project. 
Thus, while the use of organic certification was to assist the actualization of the goals of the ecological shrimp project and thus, to counter the McDonaldization and industrialization of shrimp farming, ironically, it led to the McDonaldization of ecological shrimp project. Put differently, whereas the intended objectives of industrialized and alternative forms of aquaculture are divergent-one mass production for mass consumption, the other sustainable and just production - the governance of the project and the treatment of farmers in the ecological shrimp project became quite similar to those in conventional systems. As a result, in seeking to expand the scope of the project and its impacts through a highly rationalized, bureaucratic, and market-oriented approach, the use of voluntary standards and certification eroded the original objectives of the project, and created many of the same problems associated with the industrial aquaculture, such as alienation and marginalization of farmers and a lack of trust between stakeholders.

After seeing the changes in the project and reflecting on their impacts, SN and PA decided not to renew organic certification in 2008. In interviews, they noted that while certification did have some benefits it ended up undermining many of the original aims of the ecological shrimp project. SN, PA, and the co-op consumers decided to return to the original project design and focus on trying to rebuild relationships and trust between farmers and co-op members.

\section{Conclusions}

Alternative food and agriculture movements have found voluntary standards and certification to be an effective approach for advancing their causes, and as a result, increasingly rely on them today. While based on a single case study, the findings from the ecological shrimp project raise concerns regarding the increased use of certification by alternative food and agriculture movements and highlight challenges to enhancing the sustainability and justice of food and agriculture through the use of certification. Specifically, the argument of this paper is that certification can lead to the McDonaldization of alternative agrifood initiatives, and has both benefits and drawbacks for alternative food and agriculture movements themselves, and their aims of furthering sustainability and justice.

I contend that in using certification, alternative food and agriculture movements are advancing a particular form of social change, that is, what I term McSustainability and McJustice. With McSustainability and McJustice, production practices are standardized, initiatives are organized bureaucratically, and farmers are subjects who need to be controlled and disciplined. Compared to industrialized food and agriculture, with McSustainability and McJustice, alternative food and agriculture is likely to be more sustainable in that the environmental impacts are lessened, and more just as there are price premiums for farmers. Additionally, McSustainability and McJustice allow for greater market access and geographical expansion; thus, increasing the scale and scope of alternative agriculture. Thus, McSustainability and McJustice will counteract the many of the worst environmental and social abuses of the global agrifood system. It will also allow the expansion of more environmentally sustainable and socially just practices to greater economies of scale, such as the expansion of environmental sustainability and social justice standards to planation system agriculture (e.g., Fair Trade and the Roundtable for Sustainable Palm Oil). In this way, the McDonalization of 
alternative agriculture will increase the impact of alternative food and agriculture movements and the sustainability and fairness of food and agriculture.

However, there are also limitations to the kinds of changes that McSustainability and McJustice can achieve. Most notably, with McSustainability and McJustice, sustainability and justice are limited to social and environmental issues and aspects of food and agriculture that can be measured, standardized, and validated. Given that not all aspects of sustainable farming or ethical production are easily measurable through the use of formal standards, documents, and audits, some forms of sustainability and justice are likely to be marginalized and/or excluded. Additionally, alternative agrifood practices that are inefficient and cannot be organized bureaucratically also face the threat of marginalization. For example, with McSustainability and McJustice, there is little opportunity for farmer empowerment and food sovereignty in alternative agrifood initiatives, both of which are important aims of some, if not all, alternative food and agriculture movements.

Thus, the possibility that the use of voluntary standards and certification is producing McSustainability and McJustice of food and agriculture raises important questions for proponents of alternative food and agriculture movements. First, what kinds of changes are they trying to achieve? That is, what form of sustainability and justice are they trying to advance? Second, what are the best approaches for increasing the sustainability and justice of food and agriculture? Depending on the answers to these questions, the findings of this paper indicate that alternative food and agriculture movements may need to diversify their approaches. Specifically, robust forms of environmental sustainability and such aims as farmer empowerment and food sovereignty may require other approaches in addition to certification. Hence, greater inclusion of, and experimentation with, other organizational forms and modes of governance, such as re-localization and participatory and reflexive governance, may be necessary for the realization of other forms of sustainability and justice beyond McSustainability and McJustice.

\section{Conflicts of Interest}

The author declares no conflict of interest.

\section{References and Notes}

1. Alternative food and agriculture movements are not monolithic. Rather, "alternative food and agriculture" is an umbrella term that encompasses a wide breath of movements that contest parts of industrialized food and agriculture. Thus, the word, "alternative" is used as a heuristic device for categorizing those agrifood practices that seek to counter and/or reform industrial agriculture in this article.

2. Peck, J.; Tickell, A. Neoliberalizing Space. Antipode 2002, 34, 380-404.

3. Busch, L.; Bain, C. New! Improved? The Transformation of the Global Agrifood System. Rural Sociol. 2004, 69, 321-346.

4. Hatanaka, M.; Busch, L. Third-party certification in the global agrifood system: An objective or socially mediated governance mechanism? Sociol. Rural. 2008, 48, 73-91.

5. Bartley, T. Institutional Emergence in an Era of Globalization: The Rise of Transnational Private Regulation of Labor and Environmental Conditions. Am. J. Sociol. 2007, 113, 297-351. 
6. Guthman, J. Agrarian Dreams: The Paradox of Organic Farming in California; University of California Press: Berkeley, CA, USA, 2004.

7. Buck, D.; Getz, C.; Guthman, J. From farm to table: The oganic vegetable commodity chain of northern California. Sociol. Rural. 1997, 37, 3-20.

8. Raynolds, L.; Murray, D.; Wilkinson, J. Fair Trade: The Challenges of Transforming Globalization; Routledge: New York, NY, USA, 2007.

9. Jaffee, D. Brewing Justice: Fair Trade Coffee, Sustainability, and Survival; University of California Press: Berkeley, CA, USA, 2007.

10. Ponte, S. Greener than thou: The political economy of fish ecolabeling and its local manifestations in South Africa. World Dev. 2008, 36, 159-175.

11. Bush, S.R.; Toonen, H.; Oosterveer, P.; Mol, A.P.J. The "devils triangle" of MSC certification: Balancing credibility, accessibility and continuous improvement. Mar. Policy 2013, 37, 288-293.

12. Vandergeest, P. Certification and Communities: Alternatives for Regulating the Environmental and Social Impacts of Shrimp Farming. World Dev. 2007, 35, 1152-1171.

13. Constance, D.H. Sustainable Agriculture in the United States: A Critical Examination of a Contested Process. Sustainability 2010, 2, 48-72.

14. Hatanaka, M.; Konefal, J.; Constance, D.H. A Tripartite Standards Regime Analysis of the Contested Development of a Sustainable Agriculture Standard. Agric. Hum. Values 2012, 29, 65-78.

15. Silva-Castaneda, L. A forest of evidence: Third-party certification and multiple forms of proof: A case study of oil palm plantations in Indonesia. Agric. Hum. Values 2012, 29, 361-370.

16. McCarthy, J.F. Certifying in Contested Spaces: Private regulation in Indonesian forestry and palm oil. Third World Q. 2012, 33, 1871-1888.

17. Bartley, T. Certifying Forests and Factories: States, Social Movements, and the Rise of Private Regulation in the Apparel and Forest Products Fields. Polit. Soc. 2003, 31, 433-464.

18. Soil Association. Organic Market Report 2012. Available online: http://www.soilassociation.org/ marketreport (accessed on 8 October 2013).

19. Fairtrade Foundation. Responsible Capitalism? New Fairtrade Figures Show Business is Changing for Good. Available online: http://www.fairtrade.org.uk/press_office/press_releases_and_statements/ february_2012/responsible_capitalism.aspx (accessed on 8 October 2013).

20. Fairtrade Africa. Fairtrade Growth Facts and Figures. Avaialbe online: http://www.fairtradeafrica.net/ market-info/fairtrade-growth-facts-figures) (accessed on 8 October 2013).

21. Ritzer, G. The McDonaldization of Society; SAGE Publications, Inc.: Thousand Oaks, CA, USA, 2013.

22. To maintain confidentiality, the identity of the companies involved in the organic shrimp project, as well as the project location, has been changed.

23. Weber, M. Economy and Society; University of California Press: Berkeley, CA, USA, 1978.

24. Star, S.L. Power, technology and the phenomenology of conventions: On being allergic to onions. In A Sociology of Monsters: Essays on Power, Technology and Dominatiion; Law, J., Ed.; Routledge: New York, NY, USA, 1991; pp. 26-53.

25. Schlosser, E. Fast Food Nation: The Dark Side of the All-american Meal; HarperCollins Publishers Inc.: New York, NY, USA, 2002.

26. Pollan, M. The Omnivore's Dilemma; The Penguin Press: New York, NY, USA, 2007. 
27. Magdoff, F.; Foster, J.; Buttel, F. Hungry for Profit: The Agribusiness Threat to Farmers, Food, and the Enviornment; Monthly Review Press: New York, NY, USA, 2000.

28. Kimbrell, A. The Fatal Harvest Reader: The Tragedy of Industrial Agriculture; Island Press: Washington, DC, USA, 2002.

29. Buttel, F.; Larson, O.; Gillespie, G. The Sociology of Agriculture; Greenwood Press: New York, NY, USA, 1990.

30. Buttel, F.H. Some Reflections on Late Twentieth Century Agrarian Political Economy. Sociol. Rural. 2001, 41, 165-181.

31. Friedland, W.H.; Busch, L.; Buttel, F.H.; Rudy, A.P. Towards a New Political Economy of Agriculture; Westview Press: Boulder, CO, USA, 1991.

32. Friedmann, H.; McMichael, P. Agriculture and the State System: The Rise and Decline of National Agricultures, 1870 to the Present. Sociol. Rural. 1989, 14, 93-118.

33. Blatt, H. America's Food: What You Don't Know About What You Eat; The MIT Press: Boston, MA, USA, 2011.

34. United States Department of Agriculture. 2007 Census of Agriculture. Available online: http://www.agcensus.usda.gov/Publications/2007/index.php. (accessed on 14 August 2012).

35. Newell, D.; Koopmans, K.; Verhoef, L.; Duizer, E.; Aidara-Kane, A.; Sprong, H.; Opsteegh, M.; Langelaar, M.; Threfall, J.; Scheutz, F.; et al. Food-borne diseases: The challenges of 20 years ago still persist while new ones continue to emerge. Int. J. Food Microbiol. 2010, 139, S3-S15.

36. Patel, R. Stuffed and Starved: The Hidden Battle for the World Food System; Melville House: Brooklyn, NY, USA, 2008.

37. Holt-Gimenez, E.; Shattuck, A.; Altieri, M.; Herren, H.; Gliessman, S. We Already Grow Enough Food for 10 Billion People and Still Can't End Hunger. J. Sustain. Agric. 2012, 36, 595-598.

38. Lappe, F.M. Hunger is Not a Place. Available online: http://www.thenation.com/article/hungernot-place (accessed on 11 March 2010).

39. McMichael, P. Peasants Make Their Own History, But Not Just as They Please. J. Agrar. Chang. 2008, 8, 205-228.

40. Borras, S.J. La Via Campesina and its Global Campaign for Agrarian Reform. J. Agrar. Chang. 2008, 8, 258-289.

41. Borras, S.J. The Politics of Transnational Agrarian Movements. Dev. Chang. 2010, 41, 771-803.

42. Schlosser, E. Op-Ed Contributor: A Side Order of Human Rights. Available online: http://www.nytimes.com/2005/04/06/opinion/06schlosser.html?pagewanted=2\&_r=0 (accessed on 10 September 2012).

43. Deumling, D.; Wackernagel, M.; Monfreda, C. Eathing Up the Earth: How Sustainable Food Systems Shrink Our Ecological Footprint; Redefinining Progress: Oakland, CA, USA, 2003.

44. Imhoff, D. The CAFO Reader: The Tragedy of Industrial Animal Factories; Watershed Media: Berkeley, CA, USA, 2010.

45. Schlosser, E. The Chain Never Stops. In Food and Culture; Counihan, C., van Esterik, P., Eds.; Routledge: New York, NY, USA, 2008; pp. 441-451.

46. Barndt, D. Whose "Choice"? "Flexible" Women Workers in the Tomato Food Chain. In Food and Culture; Counihan, C., van Esterik, P., Eds.; Rougledge: New York, NY, USA, 2008; pp. 452-466. 
47. Holmes, S. Fresh Fruit, Broken Bodies: Migrant Farmworkers in the United States; University of California Press: Berkeley, CA, USA, 2013.

48. Delind, L.; Howard, P. Safe at any scale? Food scares, food regulation and scaled alternatives. J. Agric. Hum. Values 2008, 25, 301-317.

49. Freidberg, S. French Beans and Food Scares: Culture and Commerce in an Anxious Age; Oxford University Press: New York, NY, USA, 2004.

50. Goodman, D. The quality "turn" and alternative food practices: Reflections and agendas. J. Rural Stud. 2003, 19, 1-7.

51. Renard, M.-C. Fair Trade: Quality, Market and Conventions. J. Rural Stud. 2003, 19, 87-96.

52. Allen, P. Together at the Table: Sustainability and Sustenance in the American Agrifood System; The Pennsylvania State University Press: University Park, PA, USA, 2004.

53. Newell, P. Environmental NGOs and Globalization: The Governance of TNCs. In Global Social Movements; Cohen, R., Rai, S.M., Eds.; Athlone Press: London, UK, 2000; pp. 117-133.

54. Higgins, V.; Lawrence, G. Agricultural Governance: Globalization and the New Politics of Regulation; Routledge: Oxon, UK, 2005.

55. Marsden, T.; Lee, R.; Flynn, A.; Thankappan, S. The New Regulation and Governance of Food: Beyond the Food Crisis? Routledge: New York, NY, USA, 2010.

56. Cashore, B.W.; Auld, G.; Newsom, D. Governing Through Markets: Forest Certification and the Emergence of Non-State Authority; Yale Unversity Press: New Haven, CT, USA, 2004.

57. Hatanaka, M.; Bain, C.; Busch, L. Third-party certification in the global agrifood system. Food Policy 2005, 30, 354-369.

58. Lockie, S. "The invisible mouth": Mobilizing "the consumer" in food production-consumption networks. Sociol. Rural. 2002, 42, 278-294.

59. Mansfield, B. Neoliberalism in the oceans: "Rationalization", property rights, and the commons question. Geoforum 2004, 35, 313-326.

60. Hatanaka, M. Trust, Certification, and Partnership in an Organic Shrimp Network: Rethinking Transnational Alternative Agrifood Networks. World Dev. 2010, 38, 706-716.

61. Food and Agriculture Organization. The State of World Fisheries and Aquaculture; FAO: Rome, Italy, 2010.

62. Halweil, B. Farming Fish for the Future; WorldWatch Institute: Washington, DC, USA, 2008; pp. 1-49.

63. McGinn, A.P. Blue Revolution: The promises and pitfalls of fish farming. World Watch Mag. 1998, 11, 10-19.

64. Stonich, S.C.; Bailey, C. Resisting the Blue Revolution: Contending Coalitions Surrounding Industrial Shrimp Farming. Hum. Organ. 2000, 59, 23-36.

65. Goss, J.; Burch, D.; Rickson, R.E. Agri-Food Restructuring and Third World Transnationals: Thailand, the CP Group and the Global Shrimp Industry. World Dev. 2000, 28, 513-530.

66. Skladany, M.; Harris, C. On global pond: International development and commodity chains in the shrimp industry. In Food and Agrarian Orders in the World-Economy; McMichael, P., Ed.; Praeger: Westport, CT, USA, 1995; pp. 169-191.

67. Barbier, E.B.; Cox, M. Does Economic Development Lead to Mangrove Loss? A Cross-Country Analysis. Contemp. Econ. Policy 2003, 21, 418-432. 
68. Barbier, E. Habitat-fishery linkages and mangrove loss in Thailand. Contemp. Econ. Policy 2003, 21, 59-77.

69. Naylor, R.L.; Goldburg, R.J.; Primavera, J.H.; Kautsky, N.; Beveridge, C.M.; Clay, J.; Folke, C.; Lubchenco, J.; Mooney, H.; Troell, M. Effect of aquaculture on world fish supplies. Nature 2000, 405, 1017-1024.

70. Kunstadter, P.; Bird, E.C.F.; Sabhasri, S. Man in the Mangroves: The Socio-Economic Situation of Human Settlements in Mangrove Forests; The United Nations University: Tokyo, Japan, 1986.

71. Shiva, V. The Damaging Social and Environmental Effects of Aquaculture. Third World Resurgence 1995, 59, 22-24.

72. Stonich, S.C.; Vandergeest, P. Violence, Environment, and Industrial Shrimp Farming. In Violent Environments; Peluso, N.L., Watts, M., Eds.; Cornell University Press: Ithaca, NY, USA, 2001; pp. 261-286.

73. Béné, C. The Good, the Bad and the Ugly: Discourse, Policy Controversies and the Role of Science in the Politics of Shrimp Farming Development. Dev. Policy Rev. 2005, 23, 585-614.

74. Lebel, L.; Lebel, P.; Garden, P.; Giap, D.H.; Khrutmuang, S.; Nakayama, S. Places, Chains, and Plates: Governing Transitions in the Shrimp Aquaculture Production-Consumption System. Globalizations 2008, 5, 211-226.

75. Bush, S.; Oosterveer, P. The Missing Link: Intersecting governance and trade in the space of place and the space of flows. Sociol. Rural. 2007, 47, 384-399.

76. Hatanaka, M. Governing Sustainability: Examining Audits and Compliance in a Third-Party Certified Organic Shrimp Farming Project in Rural Indonesia. Local Environ. 2010, 15, 233-244.

77. Bush, S.R.; Belton, B.; Hall, D.; Vandergeest, P.; Murray, F.J.; Ponte, S.; Oosterveer, P.; Islam, M.S.; Mol, P.J.; Hatanaka, M.; et al. Certify Sustainable Aquaculture? Science 2013, 341, 1067-1068.

78. KOMPHALINDO. The Blue Revolution: Another Environmental Disaster in Indonesia; KOMPHALINDO: Jakarta, Indonesia, 2001.

79. The contract with the European buyer was terminated in response to a campaign by an environmental organization that targeted Green Soil's organic standards as insufficient. For a more detailed discussion, see [58].

80. Hatanaka, M. Assessing rule-based governance mechanisms in an era of scientism. J. Rural Soc. Sci. 2010, 25, 141-158.

81. Gibbon, P.; Ponte, S. Global value chains: From governance to governmentality. Econ. Soc. 2008, 37, 365-392.

82. According to Green Soil's organic standards, polyculture was a required condition for organic production.

(C) 2014 by the author; licensee MDPI, Basel, Switzerland. This article is an open access article distributed under the terms and conditions of the Creative Commons Attribution license (http://creativecommons.org/licenses/by/4.0/). 